\title{
Using Water Quality Index for Assessing of Physicochemical Quality of Quaternary Groundwater in the Southern Part of Abidjan District (Côte d'Ivoire)
}

\author{
Aristide Gountôh Douagui ${ }^{*}$, Innocent Kouassi Kouamé1, Jules Mangoua Oi Mangoua², \\ Auguste Kouamé Kouassi' ${ }^{1}$, Issiaka Savané ${ }^{1}$
}

\begin{abstract}
${ }^{1}$ Laboratoire Géosciences et Environnement, Unité de Formation et de Recherches des Sciences et Gestion de l'Environnement, Université Nangui Abrogoua, Abidjan, Côte d'Ivoire

${ }^{2}$ Unité de Formation et de Recherches Environnement, Université Lorougnon Guédé, Daloa, Côte d'Ivoire Email: ^douaguiaristide.sge@univ-na.ci, innocent_kouassi@yahoo.fr,mjul_2@yahoo.fr, kouameauguste@yahoo.fr, savanei@hotmail.com
\end{abstract}

How to cite this paper: Douagui, A.G., Kouamé, I.K., Mangoua, J.M.O., Kouassi, A.K. and Savané, I. (2019) Using Water Quality Index for Assessing of Physicochemical Quality of Quaternary Groundwater in the Southern Part of Abidjan District (Côte d'Ivoire). Journal of Water Resource and Protection, 11, 1278-1291. https://doi.org/10.4236/jwarp.2019.1110074

Received: September 12, 2019

Accepted: October 20, 2019

Published: October 23, 2019

\section{Copyright $\odot 2019$ by author(s) and} Scientific Research Publishing Inc. This work is licensed under the Creative Commons Attribution International License (CC BY 4.0).

http://creativecommons.org/licenses/by/4.0/ (c) (i) Open Access

\begin{abstract}
In this study, fourteen physicochemical parameters were monitored at 61 groundwater sampling points located in the southern part of Abidjan District. Each water sampling location was sampled in March and July 2007, representing respectively the long dry season and the long wet season. Groundwater evaluation index and statistical methods were used to assess Quaternary groundwater physicochemical quality in term of drinking and irrigation purposes. The groundwater samples irrespective of seasons fell in mixed $\mathrm{K}-\mathrm{Na}-\mathrm{HCO}_{3}$ and $\mathrm{K}-\mathrm{Na}-\mathrm{Cl}$ types. Groundwater quality index values varied from 14.01 to 593.44 and from 20.88 to 567.44 , in dry and rainy seasons, respectively. In both seasons, $9.83 \%$ exhibited poor water quality and $3.27 \%$ indicated unsuitable water for drinking purposes. The studied water wells were heavily contaminated with nitrate, nitrite and ammonium in the strongly urbanized areas at Treichville, Koumassi, Marcory, Port-Bouët and Grand-Bassam. The degree of correlation between physicochemical parameters suggested that groundwater quality was mainly related to geogenic (rock-water interaction) and anthropogenic sources (domestic sewage), and intrusion of marine and lagoon waters in the study area. Sodium adsorption ratio was generally low during study period, indicating most groundwater sampled was suitable for irrigation purposes.
\end{abstract}

\section{Keywords}

Hydrochemistry, Groundwater Quality, Chemical Pollution, Abidjan District 


\section{Introduction}

Groundwater has become the major source of water supply for drinking, domestic, household, agricultural, industrial and environmental activities. This has led to an increase in the demand of water supply which is met mostly from the exploitation of groundwater resources. Studies like [1]-[9] showed that in many African cities, groundwater is a vital water source outside of surface water resources. The wise management of groundwater resources is fundamental for sustainable development for reliable water sources supply for urban and rural areas.

Determination of groundwater quality is important for assessing various usages. Variation in groundwater quality in an area is a function of physical and chemical parameters that are greatly influenced by natural processes such as geological formations and anthropogenic activities [10]. The study of hydrogeochemical processes in groundwater helps to understand and distinguish between the rock-water interactions and anthropogenic influences. The geochemical processes occuring within the groundwater and the reaction with aquifer minerals have a profound effect on water quality [11] [12]. Groundwater chemically evolves by interaction with aquifer minerals or internal mixing of different groundwaters along subsurface flow-paths [11] [13]. Therefore spatial distribution of chemical species gives some idea about the direction of groundwater movement.

In the southern part of Abidjan District, groundwater supplies from Quaternary formations represent the most important groundwater resource for a large percentage of suburban and rural populations. These low-income communities live in areas without organized waste disposal systems and where poorly managed municipal landfills exist [14]. Recent research results [10] [12] [15] showed that negligence, improper management of domestic waste and the use of septic tanks, and soak-away pits in these areas produce leachates into the groundwater that cause chemical pollution. Many low-income communities that do not have access to clean drinking water have become increasingly reliant on untreated well and borehole water for drinking, domestic activities and farm irrigation. However, [16] indicated that this Quaternary aquifer is vulnerable to contamination due to inherent geological properties. Indeed, the sandy formations in this coastal zone, characterized by high permeability, are likely to facilitate contaminants' migration to the groundwater. Previous case studies [16] [17] have shown high levels of nitrate and fecal germs in some wells in the southern area of Abidjan district. However, these studies did not include temporal and spatial changes in groundwater quality. Thus, there is a need to conduct these types of studies to assist local authorities in developing plans and regulations and in implementing actions to reduce human health and environmental risks.

The objective of this work is to evaluate the physicochemical quality of Quaternary groundwater on suitability for drinking and irrigation purposes. 


\section{Materials and Methods}

\subsection{Study Area}

The study area is located in the South of Côte d'Ivoire. It covers the area between latitude $5^{\circ} 12^{\prime} 5^{\prime \prime} \mathrm{N}$ and $5^{\circ} 20^{\prime} 15^{\prime \prime N}$ North and longitude $4^{\circ} 4^{\prime} 57^{\prime \prime} \mathrm{W}$ and $3^{\circ} 43^{\prime} 19^{\prime \prime} \mathrm{W}$. It is divided into five communal zones namely Treichville, Marcory, Koumassi, Port-Bouët and Grand-Bassam (Figure 1). The population is estimated at 880,712 inhabitants [14]. This area is under the influence of the equatorial transition climate with four distinct seasons: a long dry season (December to April), a long rainy season (May to July), a short dry season (August to September) and a short rainy season (October to November). The annual rainfall recorded the Port-Bouët weather station over the period 2005-2009 varies from 1595.3 to $2048.2 \mathrm{~mm}$ with an average of $1724.30 \mathrm{~mm}$ [18]. The long rainy season is centered on June while the short rainy season is on November. The long and the short dry seasons are centered on January and August, respectively. The study area is located in the coastal sedimentary basin and covers $253 \mathrm{~km}^{2}$ and is characterized by a flat relief. Various geological formations of Quaternary age are found in this zone. These include clayey sands reaching 15 to $30 \mathrm{~m}$ thickness, mud and sands from the fluvio-lagunal depression, and marine sands reaching up to $45 \mathrm{~m}$ thickness. It is a sandy aquifer that receives high recharge. The permeability of the surface deposits of this aquifer system ranges from $10^{-4}$ to $10^{-3} \mathrm{~m} \cdot \mathrm{s}^{-1}$ for the clayey sands and $10^{-3} \mathrm{~m} \cdot \mathrm{s}^{-1}$ for marine sands [19]. Groundwater flow velocity in the aquifer is high and can be regarded as relatively uniform.

\subsection{Groundwater Samples and Data Collection}

Groundwater was sampled from 61 locations (59 wells and 2 boreholes) during the long dry and rainy seasons of 2007 (March and July). The sampling points were selected based on the geographic location of wells and boreholes and the use of the wells and boreholes as sources of drinking water. Figure 2 shows the location of the selected wells and boreholes. Water sample collection from wells and boreholes was carried out according to the procedures described by [20] and [21]. Samples from wells were collected with weighted buckets $(50 \mathrm{~cm}$ below the water table). For boreholes, samples were taken after pumping for 5 min. The tap and the bucket were cleaned before sampling and caution was taken to avoid splashing. Samples were collected in $500 \mathrm{~mL}$ polyethylene bottles. Once collected, all samples were stored on ice and immediately transported to the laboratory. Chemical analyses were processed within 6 hours after collection.

The preliminary field investigation was used to determine the proximity of the wells and boreholes to sources of pollution, the nature of surroundings, the depth of wells and boreholes, soil type, fertilizer use and materials used for coverage of wells. 


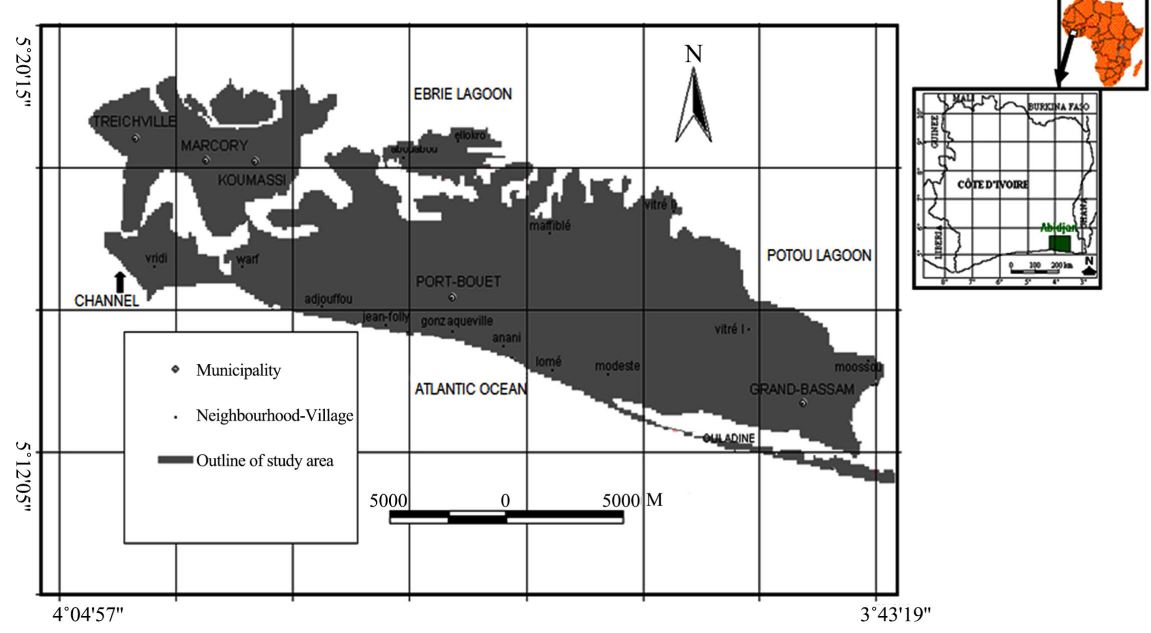

Figure 1. Study area.

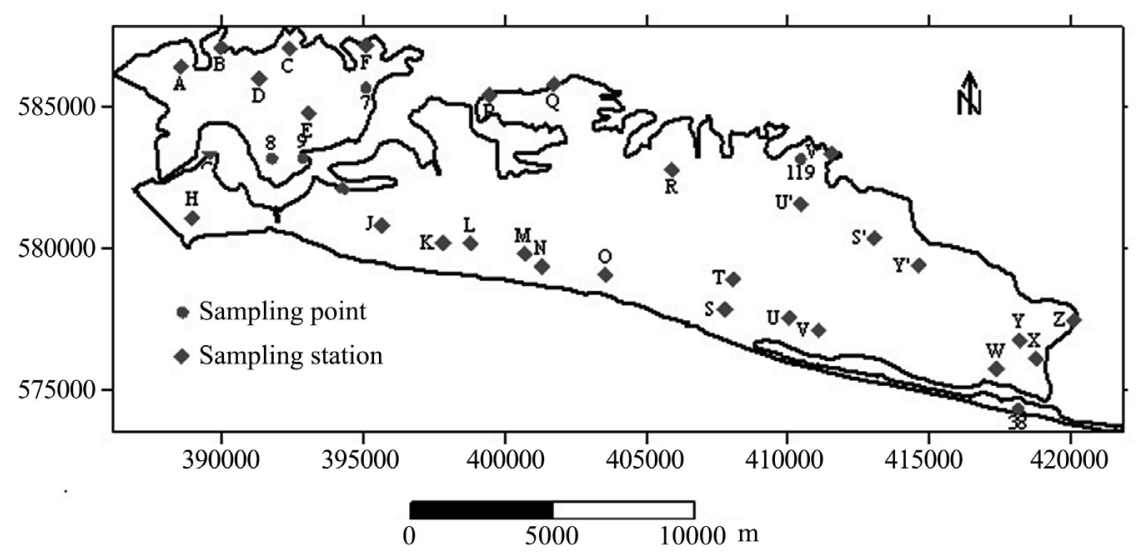

Figure 2. Location of sampling points. Sampling points 1 - $4 ; 5 ; 10 ; 11 ; 6 ; 12,13 ; 14$ - 16; 18 - 20; 21 - 23; 24, 25; 26, 27; 32, 33; F1; 30, 31; 28, F2; 34 - 37; 38, 39; 40, 41; 42, 45; 44; 46; 47 - 49; 53, 54; 59 - 61; 55 - 57 and 50 - 52 are located in A, B, C, D, F, H, J, K, L, M, N, $\mathrm{O}, \mathrm{P}, \mathrm{Q}, \mathrm{R}, \mathrm{S}, \mathrm{U}, \mathrm{V}, \mathrm{W}, \mathrm{X}, \mathrm{Y}, \mathrm{Z}, \mathrm{S}^{\prime}, \mathrm{U}^{\prime}, \mathrm{V}^{\prime}$ and Y', respectively.

\subsection{Physicochemical Analyses}

$\mathrm{pH}$, electrical conductivity (EC) and salinity were measured in situ using the Hach Model 44,600 Meter. Nitrate, nitrite, ammonium, sulfate and phosphate were analyzed by spectrometry according to AFNOR standards NFT 90-013, NFT 90-012, NFT 90-015, NFT 90-040, NFT 90-023, using a JASCOV-530 molecular absorption spectrometer controlled by a computer. Sodium, potassium, calcium and magnesium concentrations were measured using atomic absorption spectrometry, according to AFNOR standards NFT 90-020 and NFT 90-112. Hydrogenocarbonate and chloride concentrations were measured using titrimetric method according to AFNOR standards NFT 90-036 and NFT 90-014.

Correlation studies were carried out using the Spearman correlation test to determine the relationships between physicochemical parameters. The Spearman correlation tests were carried out using data obtained from 122 monthly-average 
(March and July) samplings in the sixty-one wells and boreholes.

\subsection{Groundwater Pollution Evaluation}

Groundwater quality index (GWQI) method reflects the composite influence of the different water quality parameters on the suitability for drinking purposes. The standards for drinking purposes as recommended by [22] have been considered for the calculation of GWQI. For computing GWQI three steps are followed as described by [23]. In the first step, each of the 14 physicochemical parameters $\left(\mathrm{pH}, \mathrm{EC}\right.$, salinity, $\mathrm{NO}_{3}^{-}, \mathrm{NO}_{2}^{-}, \mathrm{NH}_{4}^{+}, \mathrm{SO}_{4}^{2-}, \mathrm{PO}_{4}^{3-}, \mathrm{Na}^{+}, \mathrm{K}^{+}, \mathrm{Ca}^{2+}$, $\left.\mathrm{Mg}^{2+}, \mathrm{HCO}_{3}^{-}, \mathrm{Cl}^{-}\right)$has been assigned a weight $\left(w_{i}\right)$ according to its relative importance in the overall quality of water for drinking purposes (Table 1). The maximum weight of 5 has been assigned to the parameters like nitrate, nitrite, ammonium and phosphate due to their major importance in water quality assessment. Other parameters were assigned weight between 1 and 4 depending on their importance in water quality determination. In the second step, the relative weight $\left(W_{i}\right)$ is computed as follows (Equation (1)):

$$
W_{i}=\frac{w_{i}}{\sum_{i=1}^{n} w_{i}}
$$

where $W_{i}$ is the relative weight, $W_{i}$ is the weight of each parameter, $n$ is the number of parameters.

In the third step, a quality rating scale $\left(q_{i}\right)$ for each parameter is assigned by dividing its concentration in each water sample by its respective standard (Equation (2)) according to [22] acceptability and health-based of drinking-water guidelines or limit values defined by [23] and [24].

$$
q_{i}=\left(\frac{C_{i}}{S_{i}}\right) \times 100
$$

where, $q_{i}$ is the quality rating; $C_{i}$ is the value or concentration of each parameter in each water sample; $S_{i}$ is the drinking water standard for each parameter.

For computing the GWQI, the SI is first determined for each parameter (Equation (3)), which is then used to determine the GWQI. GWQI is defined as (Equation (4)):

$$
\begin{gathered}
S I_{i}=W_{i} \times q_{i} \\
\text { GWQI }=\sum S I_{i}
\end{gathered}
$$

where $S I_{i}$ is the sub-index of $i$ th parameter; $q_{i}$ is the rating based on value or concentration of $i$ th parameter; $\mathrm{n}$ is the number of parameters.

The GWQI range and type of water are classified as follows [24] (Table 2):

\subsection{Evaluation of Water Quality for Irrigation Purposes}

Sodium adsorption ratio (SAR) can be used to evaluate irrigation water quality [23]. The SAR recommended by the US Salinity Laboratory [25] is defined as follows: 
Table 1. List of parameters, weight factors, and limit values for the water quality index.

\begin{tabular}{|c|c|c|c|}
\hline Parameters & $\begin{array}{l}\text { WHO Standard (2011) } \\
\text { (acceptability and health-based of } \\
\text { drinking-water guideline values) }\end{array}$ & $\begin{array}{l}\text { Weight } \\
\left(w_{i}\right)\end{array}$ & $\begin{array}{c}\text { Relative } \\
\text { weight }\left(W_{i}\right)\end{array}$ \\
\hline $\mathrm{pH}$ & & 4 & 0.08 \\
\hline EC & & 4 & 0.08 \\
\hline Salinity & & 4 & 0.08 \\
\hline $\mathrm{NO}_{3}^{-}$ & $50 \mathrm{mg} \cdot \mathrm{L}^{-1}$ & 5 & 0.1 \\
\hline $\mathrm{NO}_{2}^{-}$ & $3 \mathrm{mg} \cdot \mathrm{L}^{-1}$ & 5 & 0.1 \\
\hline $\mathrm{NH}_{4}^{+}$ & $0.2 \mathrm{mg} \cdot \mathrm{L}^{-1}$ & 5 & 0.1 \\
\hline $\mathrm{SO}_{4}^{2-}$ & $250 \mathrm{mg} \cdot \mathrm{L}^{-1}$ & 2 & 0.04 \\
\hline $\mathrm{PO}_{4}^{3-}$ & & 5 & 0.1 \\
\hline $\mathrm{Na}^{+}$ & $200 \mathrm{mg} \cdot \mathrm{L}^{-1}$ & 2 & 0.04 \\
\hline $\mathrm{K}^{+}$ & & 4 & 0.08 \\
\hline $\mathrm{Ca}^{2+}$ & $100 \mathrm{mg} \cdot \mathrm{L}^{-1}$ & 2 & 0.04 \\
\hline $\mathrm{Mg}^{2+}$ & $50 \mathrm{mg} \cdot \mathrm{L}^{-1}$ & 2 & 0.04 \\
\hline $\mathrm{HCO}_{3}^{-}$ & & 2 & 0.04 \\
\hline \multirow[t]{2}{*}{$\mathrm{Cl}^{-}$} & $250 \mathrm{mg} \cdot \mathrm{L}^{-1}$ & 4 & 0.08 \\
\hline & & $\sum w_{i}=50$ & $\sum W_{i}=1$ \\
\hline
\end{tabular}

Table 2. GWQI range and type of water.

\begin{tabular}{cc}
\hline Range & Type of water \\
\hline$<50$ & Excellent water \\
$50-100$ & Good water \\
$100.1-200$ & Poor water \\
$200.1-300$ & Very poor water \\
$>300$ & Water unsuitable for drinking \\
\end{tabular}

$$
\begin{gathered}
\mathrm{SAR}=\frac{\mathrm{Na}}{\sqrt{\frac{\mathrm{Ca}+\mathrm{Mg}}{2}}}\left(1+8.4-\mathrm{pH}_{\mathrm{c}}\right) \\
\mathrm{pH}_{\mathrm{c}}=\left(\mathrm{pK}_{2}^{\prime}-\mathrm{pK}_{\mathrm{c}}^{\prime}\right)+\mathrm{p}(\mathrm{Ca}+\mathrm{Mg})+\mathrm{pAlK}
\end{gathered}
$$

$\mathrm{Na}, \mathrm{Ca}$ and $\mathrm{Mg}$ are the concentrations (meq $\cdot \mathrm{L}^{-1}$ ) of sodium, calcium and magnesium, respectively; $\mathrm{pK}_{2}^{\prime}$ is a constant that characterizes the 2 nd equilibrium of carbon dioxide dissolved in water; $\mathrm{pK}_{\mathrm{c}}^{\prime}$ defines the dissolution equilibrium of calcium carbonate; $\mathrm{pH}_{\mathrm{c}}$ corresponds to the $\mathrm{pH}$ value that water should have (with its own mineral composition) to be in equilibrium with calcium carbonate. 


\section{Results and Discussion}

\subsection{General Characteristics of Groundwater Quality}

General characteristics of groundwater physicochemical parameters for the study area are summarized in Table 3. $\mathrm{pH}$ values varied from 3.92 to 6.55 in March and from 5.10 to 7.97 in July. But $93 \%$ of all pH values of groundwater samples had their $\mathrm{pH}$ in the range of $\mathrm{pH} 3.1$ - 6.6 during the period of study, indicating acidic nature of the samples.

EC values varied from 50 to $1471 \mu \mathrm{S} \cdot \mathrm{cm}^{-1}$ and from 57 to $1317 \mu \mathrm{S} \cdot \mathrm{cm}^{-1}$ respectively in March and July. EC values are directly related to the ionic concentrations present in the groundwater and its higher values contribute to higher salinity and total dissolved concentration [10].

The highest concentrations of nitrate, nitrite and ammonium were recorded during the rainy period, while their low levels were found during the dry period. Groundwater nitrate, nitrite and ammonium pollution $\left(\mathrm{NO}_{3}^{-} \geq 50 \mathrm{mg} \cdot \mathrm{L}^{-1}\right.$, $\left.\mathrm{NO}_{2}^{-} \geq 3 \mathrm{mg} \cdot \mathrm{L}^{-1}, \quad \mathrm{NH}_{4}^{+} \geq 0.2 \mathrm{mg} \cdot \mathrm{L}^{-1}\right)$ occurred in the strongly urbanized areas at Treichville $(1 ; 2 ; 3 ; 4)$, Koumassi $(10 ; 7 ; 6 ; 5)$, Marcory $(8 ; 9)$, Port-Bouët (12; $13 ; 14 ; 15 ; 18 ; 19 ; 22 ; 23 ; 24 ; 25 ; 26 ; 32 ; 33 ; 34 ; 36 ; 37)$ and Grand-Bassam $(42 ; 43$; $44 ; 45 ; 46 ; 48 ; 49)$. This is in agreement with the work carried out by [14] [16] and [17]. These authors found high nitrate, nitrite and ammonium concentrations in wells at Treichville, Koumassi, Marcory and Port-Bouët. In these zones, insalubrity is growing with the direct discharge of solid waste and wastewater on the ground. These practices lead to the formation of nitrates in the ground and their transfer towards the groundwater by runoff.

Table 3. Descriptive statistics of physicochemical parameters in the study area.

\begin{tabular}{cccccccccc}
\hline \multirow{2}{*}{ Parameters } & Unit & \multicolumn{5}{c}{ Dry period } & \multicolumn{5}{c}{ Rainy period } \\
\cline { 3 - 10 } & & Min & Max & Mean & Std.Dev. & Min & Max & Mean & Std.Dev. \\
\hline $\mathrm{pH}$ & & 3.920 & 6.550 & 5.367 & 0.66 & 5.100 & 7.970 & 6.331 & 0.54 \\
Salinity & $\%$ & 0.000 & 0.500 & 0.034 & 0.099 & 0.000 & 0.500 & 0.043 & 0.09 \\
$\mathrm{EC}$ & $\mu \mathrm{S} \cdot \mathrm{cm}^{-1}$ & 50.000 & 1471.000 & 366.656 & 304.31 & 57.000 & 1317.000 & 380.328 & 298.10 \\
$\mathrm{NO}_{3}^{-}$ & $\mathrm{mg} \cdot \mathrm{L}^{-1}$ & 4.000 & 95.100 & 28.257 & 18.75 & 9.000 & 99.000 & 38.991 & 21.49 \\
$\mathrm{NO}_{2}^{-}$ & $\mathrm{mg} \cdot \mathrm{L}^{-1}$ & 0.000 & 29.000 & 3.448 & 4.87 & 0.000 & 32.000 & 4.743 & 6.23 \\
$\mathrm{NH}_{4}^{+}$ & $\mathrm{mg} \cdot \mathrm{L}^{-1}$ & 0.000 & 1.290 & 0.092 & 0.19 & 0.000 & 1.580 & 0.140 & 0.29 \\
$\mathrm{SO}_{4}^{2-}$ & $\mathrm{mg} \cdot \mathrm{L}^{-1}$ & 15.000 & 115.200 & 46.570 & 24.65 & 2.700 & 93.300 & 27.844 & 23.99 \\
$\mathrm{PO}_{4}^{3-}$ & $\mathrm{mg} \cdot \mathrm{L}^{-1}$ & 0.030 & 7.680 & 0.407 & 1.19 & 0.023 & 7.000 & 0.346 & 1.05 \\
$\mathrm{Na}^{+}$ & $\mathrm{mg} \cdot \mathrm{L}^{-1}$ & 6.000 & 94.000 & 41.376 & 24.92 & 9.000 & 97.000 & 44.404 & 24.93 \\
$\mathrm{~K}^{+}$ & $\mathrm{mg} \cdot \mathrm{L}^{-1}$ & 0.290 & 47.000 & 10.143 & 10.97 & 4.380 & 14.680 & 12.197 & 1.97 \\
$\mathrm{Ca}^{2+}$ & $\mathrm{mg} \cdot \mathrm{L}^{-1}$ & 0.073 & 6.260 & 2.255 & 1.61 & 0.000 & 28.500 & 3.691 & 5.66 \\
$\mathrm{Mg}^{2+}$ & $\mathrm{mg} \cdot \mathrm{L}^{-1}$ & 0.060 & 6.000 & 1.812 & 1.033 & 0.000 & 2.195 & 1.747 & 0.31 \\
$\mathrm{HCO}_{3}^{-}$ & $\mathrm{mg} \cdot \mathrm{L}^{-1}$ & 11.100 & 2013.000 & 204.598 & 297.28 & 29.900 & 109.800 & 88.158 & 13.42 \\
$\mathrm{Cl}^{-}$ & $\mathrm{mg} \cdot \mathrm{L}^{-1}$ & 10.000 & 88.750 & 39.189 & 19.42 & 20.000 & 32.750 & 27.778 & 0.140 \\
\hline & & & & & & & & & \\
\hline
\end{tabular}


Sulfate, phosphate, calcium, magnesium, chloride and bicarbonate concentrations were higher during the dry season (Table 3). Compared with the acceptability of drinking-water guideline proposed by [22], groundwater samples presented low concentrations of major elements $\left(\mathrm{Ca}^{2+}, \mathrm{Mg}^{2+}, \mathrm{K}^{+}, \mathrm{SO}_{4}^{2-}, \mathrm{Na}^{+}\right.$and $\mathrm{Cl}^{-}$) during the study period. We noted a dominance of the major ions $\mathrm{HCO}_{3}^{-}$, $\mathrm{Cl}^{-}, \mathrm{Na}^{+}$and $\mathrm{K}^{+}$in these groundwater samples while other ions such as $\mathrm{Ca}^{2+}$, $\mathrm{Mg}^{2+}$ and $\mathrm{SO}_{4}^{2-}$ are comparatively less represented. Concentrations of major cations and major anions were classified as:

$\left(\mathrm{Na}^{+}+\mathrm{K}^{+}\right)>\mathrm{Ca}^{2+}>\mathrm{Mg}^{2+}$ and $\mathrm{HCO}_{3}^{-}>\left(\mathrm{Cl}^{-}+\mathrm{NO}_{3}^{-}\right)>\mathrm{SO}_{4}^{2-} /\left(\mathrm{Cl}^{-}+\right.$ $\left.\mathrm{NO}_{3}^{-}\right)>\mathrm{HCO}_{3}^{-}>\mathrm{SO}_{4}^{2-}$. Thus, majority of groundwater samples irrespective of seasons fell in mixed $\mathrm{K}-\mathrm{Na}-\mathrm{HCO}_{3}$ type and $\mathrm{K}-\mathrm{Na}-\mathrm{Cl}$ type.

\subsection{Groundwater Quality for Drinking Purposes}

Table 4 shows groundwater quality types determined on the basis of GWQI for assessing the suitability of groundwater quality for drinking purposes. GWQI values varied from 14.01 to 593.44 in March and from 20.88 to 567.44, respectively. The critical limit (100) for drinking water purposes has been proposed by [23] and [24]. Table 4 shows that $13.1 \%$ of groundwater samples exceeded the critical limit (100) of GWQIs. Among the total groundwater samples, $70.49 \%$ of samples in dry season and $55.73 \%$ in rainy season belong to excellent water quality and $16.39 \%$ and $31.14 \%$ represented good water quality, in dry and rainy seasons, respectively. In both seasons, 9.83\% exhibit poor water quality and the rest of $3.27 \%$ indicated unsuitable water for drinking purposes (Table 4).

Table 4. Pollution potential of groundwater samples of the study area based on GWQI.

\begin{tabular}{|c|c|c|c|c|c|}
\hline Period & $\begin{array}{l}\text { GWQI } \\
\text { values }\end{array}$ & $\begin{array}{l}\text { Groundwater } \\
\text { quality types }\end{array}$ & $\begin{array}{l}\text { Number } \\
\text { of samples }\end{array}$ & $\begin{array}{l}\% \text { of } \\
\text { s samples }\end{array}$ & Samples \\
\hline \multirow{5}{*}{$\begin{array}{l}\text { Dry } \\
\text { season }\end{array}$} & $<50$ & Excellent water & 43 & 70.49 & $\begin{array}{l}1,5,7,10,11,15,16, \mathrm{~B} 1,20,21,22, \\
23,24,25,26,27,28, \mathrm{~B} 2,30,31,32, \\
33,34,35,36,118,39,40,41,42,45, \\
50,51,52,53,54,55,56,57,119,59, \\
60,61\end{array}$ \\
\hline & $50-100$ & Good water & 10 & 16.39 & $2,3,4,6,13,18,19,38,44,46$ \\
\hline & $100.1-20$ & Poor water & 6 & 9.83 & $8,12,14,37,47,49$ \\
\hline & $200.1-30$ & Very poor water & 0 & 0 & \\
\hline & $>300$ & $\begin{array}{l}\text { Water unsuitable for } \\
\text { drinking purposes }\end{array}$ & 2 & 3.27 & 9,48 \\
\hline \multirow{5}{*}{$\begin{array}{l}\text { Rainy } \\
\text { season }\end{array}$} & $<50$ & Excellent water & 34 & 55.73 & $\begin{array}{l}1,5,11,15,16, \mathrm{~B} 1,20,21,22,23,24, \\
25,27,28, \mathrm{~F} 2,30,34,35,36,118,39, \\
40,41,50,51,52,53,54,56,57,119, \\
59,60,61\end{array}$ \\
\hline & $50-100$ & Good water & 19 & 31.14 & $\begin{array}{l}2,3,4,6,7,10,13,14,19,26,31,32, \\
33,42,38,44,45,46,55\end{array}$ \\
\hline & \multicolumn{2}{|c|}{100.1 - 200 Poor water } & 6 & 9.83 & $8,12,18,37,47,49$ \\
\hline & \multicolumn{2}{|c|}{200.1 - 300 Very poor water } & 0 & 0 & \\
\hline & $>300$ & $\begin{array}{l}\text { Water unsuitable for } \\
\text { drinking } \\
\text { purposes }\end{array}$ & 2 & 3.27 & 9,48 \\
\hline
\end{tabular}




\subsection{Relationships between Groundwater Physicochemical Quality}

Statistically significant relationships between physicochemical parameters were found in water wells coming from different localities (Table 5). $\mathrm{NO}_{3}^{-} \quad(r=0.79$; $p<0.05), \mathrm{NH}_{4}^{+} \quad(r=0.90 ; p<0.05)$ and $\mathrm{Na}^{+}(r=0.98 ; p<0.05)$ concentrations showed a positive correlation with EC in the groundwater well of Treichville, Marcory and Koumassi (Table 5). In these localities, there was a significant positive relationship ( $r=0.81 ; p<0.05$ ) between nitrate and sodium (Table 5). These correlations may mean that the origin of contamination was the same for sodium and nitrate and ammonium. The infiltration of wastewater caused an aquifer contamination with sodium and nitrogen $(\mathrm{N})$ compounds (ammonium, nitrite and nitrate), the degree of contamination largely depending on rainfall patterns.

This hypothesis is justified by the significant variation in nitrate loading between the nearest and farthest wells from the latrines (Figure 3). Thus, nitrate concentrations recorded in these localities tend to increase in the water points closest to the latrines.

In addition, [18] indicated that in these municipalities, there is a water infiltration from Ebrié lagoon into the groundwater which could be another source of $\mathrm{NO}_{3}^{-}$and $\mathrm{Na}^{+}$ions.

Positive relationships were observed between EC values and potassium ( $r=$ $0.71 ; p<0.05)$, sodium $(r=0.77 ; p<0.05)$, sulfate $(r=0.70 ; p<0.05)$ and chloride $(r=0.73 ; p<0.05)$ in water from Vridi, Jean-Folly, Gonzaqueville and Grand-Bassam (Table 6). In these urban areas near the Atlantic Ocean, these ions could result from contamination of the groundwater by domestic wastewater and/or marine waters. Indeed, it is generally observed in coastal areas that groundwater discharged towards the Atlantic Ocean (Figure 4). However, at Vridi and Jean-Folly (Port-Bouët) and Grand-Bassam, an inversion of the hydraulic gradient was observed, resulting in an intrusion of marine waters.

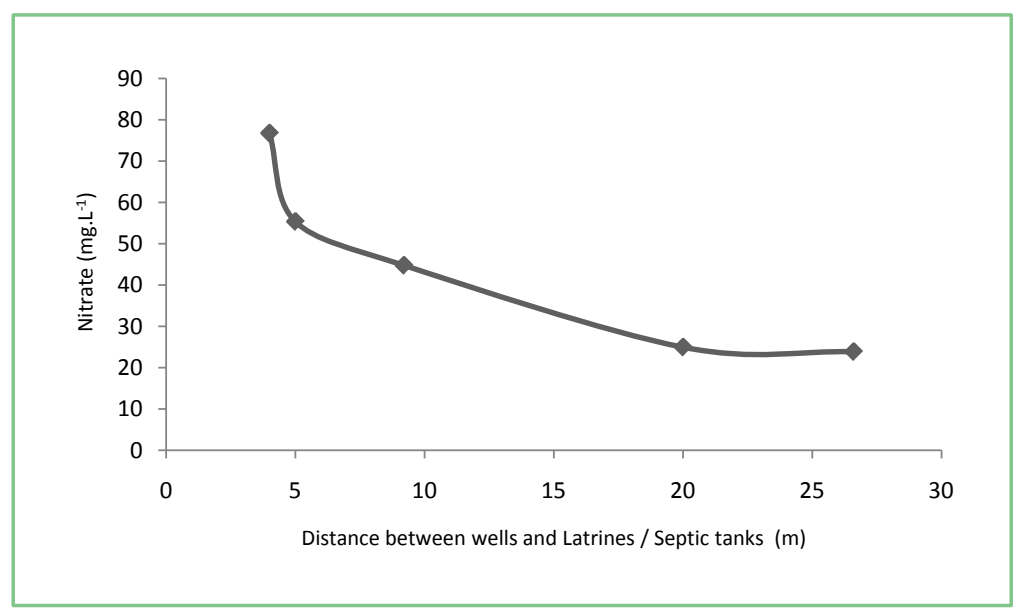

Figure 3. Variation of nitrate concentrations in relation to the distance between wells and latrines/septic tanks in the groundwater sampled in Treichville and Koumassi. 


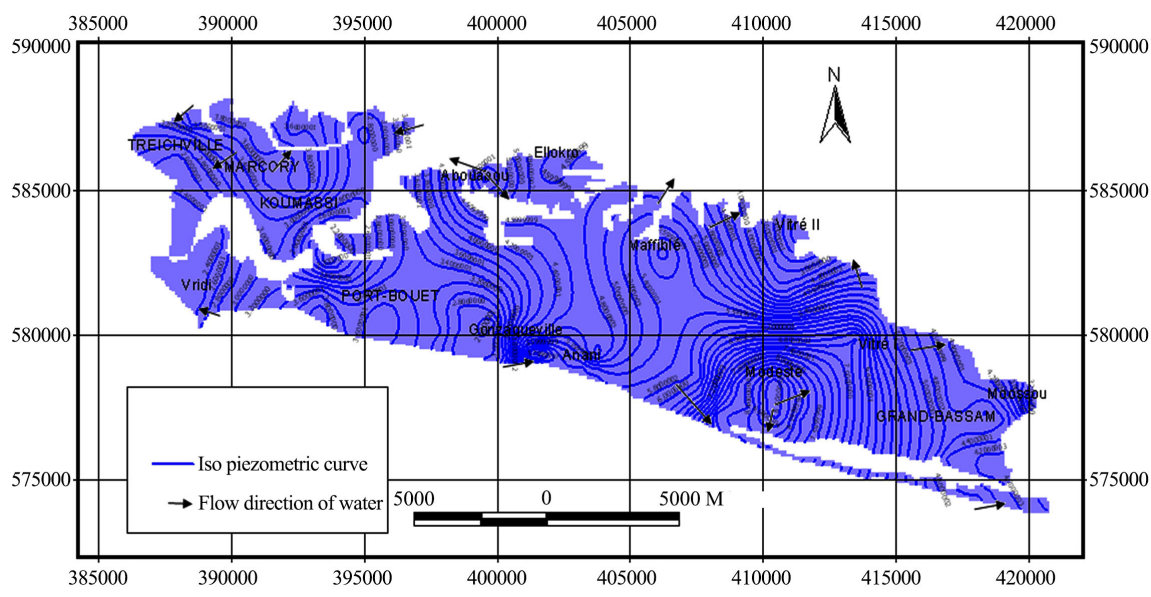

Figure 4. Piezometric map of Quaternary groundwater for the dry season of the study area.

Table 5. Spearman correlation coefficients $(r)$ between physicochemical in the groundwater well of Treichville, Marcory and Koumassi.

\begin{tabular}{ccccccc}
\hline & $\mathrm{EC}$ & $\mathrm{NO}_{3}^{-}$ & $\mathrm{Na}^{+}$ & $\mathrm{NH}_{4}^{+}$ & $\mathrm{PO}_{4}^{3-}$ & $\mathrm{NO}_{2}^{-}$ \\
\hline $\mathrm{EC}$ & 1 & & & & & \\
$\mathrm{NO}_{3}^{-}$ & $0.79^{*}$ & 1 & & & & \\
$\mathrm{Na}^{+}$ & $0.98^{*}$ & $0.81^{*}$ & 1 & & & \\
$\mathrm{NH}_{4}^{+}$ & $0.90^{*}$ & - & - & 1 & & \\
$\mathrm{PO}_{4}^{3-}$ & - & $-0.63^{*}$ & $-0.74^{*}$ & - & 1 & 1 \\
$\mathrm{NO}_{2}^{-}$ & - & - & - & $-0.91^{*}$ & & 1 \\
\hline
\end{tabular}

$-p>0.05 ;{ }^{*} p<0.05$ for $0.63 \leq|r|<0.92$.

Table 6. Spearman correlation coefficients $(r)$ between physicochemical in the groundwater well of Port-Bouët (Vridi, Jean-Folly, Gonzaqueville) and Grand-Bassam.

\begin{tabular}{cccccccc}
\hline & $\mathrm{EC}$ & $\mathrm{K}^{+}$ & $\mathrm{Na}^{+}$ & $\mathrm{SO}_{4}^{2-}$ & $\mathrm{Cl}^{-}$ & $\mathrm{HCO}_{3}^{-}$ & $\mathrm{Mg}^{2+}$ \\
\hline $\mathrm{EC}$ & 1 & & & & & & \\
$\mathrm{~K}^{+}$ & $0.71^{*}$ & 1 & & & & & \\
$\mathrm{Na}^{+}$ & $0.77^{*}$ & $0.71^{*}$ & 1 & & & & \\
$\mathrm{SO}_{4}^{2-}$ & $0.70^{*}$ & $0.65^{*}$ & - & 1 & & & \\
$\mathrm{Cl}^{-}$ & $0.73^{*}$ & $0.92^{*}$ & $0.85^{*}$ & - & 1 & & \\
$\mathrm{HCO}_{3}^{-}$ & - & $0.69^{*}$ & - & $0.87^{*}$ & - & 1 & \\
$\mathrm{Mg}^{2+}$ & - & $0.81^{*}$ & $0.85^{*}$ & - & $0.95^{*}$ & & 1 \\
\hline
\end{tabular}

$-p>0.05 ;{ }^{*} p<0.05$ for $0.65 \leq r<0.96$.

\subsection{Water Quality for Irrigation Purposes}

SAR values greater than 6 indicate groundwater is unsuitable for irrigation purposes [25]. During dry season, SAR was ranging from -8.11 to $14.66 \mathrm{meq} \cdot \mathrm{L}^{-1}$ indicating $90.10 \%$ of groundwater samples were suitable for irrigation purposes 
(Table 7). In rainy season, SAR of all groundwater samples indicated values less than 6 . This means that during the rainy period, all groundwater samples were suitable for irrigation purposes (Table 7).

Table 7. Calculation of SAR for individual groundwater samples.

\begin{tabular}{|c|c|c|c|c|c|}
\hline \multirow{2}{*}{$\begin{array}{c}\text { Groudwater } \\
\text { sample number }\end{array}$} & \multicolumn{2}{|c|}{ SAR } & \multirow{2}{*}{$\begin{array}{c}\text { Groudwater sample } \\
\text { number }\end{array}$} & \multicolumn{2}{|c|}{ SAR } \\
\hline & Dry season & Rainy season & & Dry season & Rainy season \\
\hline 1 & 2.20648698 & 1.58807413 & 32 & 0.30924925 & 0.76742131 \\
\hline 2 & -2.4077449 & 1.78341067 & 33 & 1.71208822 & 1.20594321 \\
\hline 3 & 6.02011309 & 2.18130973 & 34 & -2.11055104 & 0.22274317 \\
\hline 4 & -5.63022026 & 0.08906417 & 35 & -3.96928578 & 0.85174625 \\
\hline 7 & 6.88704424 & -0.12530881 & 36 & -4.24753688 & 0.90374439 \\
\hline 6 & 5.77573675 & 2.92902537 & 37 & 3.78436754 & 0.82235364 \\
\hline 5 & 5.23647516 & 2.37779412 & 118 & -1.83830121 & 0.8626531 \\
\hline 8 & 14.6602097 & 4.01919109 & 39 & 1.57624217 & 0.85536746 \\
\hline 9 & 1.2081774 & 0.45885707 & 40 & 0.25291683 & 0.87712417 \\
\hline 10 & 6.88704424 & -0.12530881 & 41 & -1.54099393 & 0.84290235 \\
\hline 11 & 4.92477818 & 2.37779412 & 42 & -0.2091617 & 0.66142736 \\
\hline 12 & 8.44097474 & 2.07177961 & 38 & 4.26379633 & 1.89937933 \\
\hline 13 & 7.6233016 & 2.19252468 & 44 & 3.25640733 & 0.9364742 \\
\hline 14 & 3.89234368 & 1.30685304 & 45 & 1.3804672 & 0.57323705 \\
\hline 15 & 1.71358537 & 0.73353521 & 46 & 4.82576026 & 1.08054716 \\
\hline 16 & -0.54041269 & 1.13494039 & 47 & 0.93305959 & -6.626977 \\
\hline $\mathrm{B} 1$ & 0.42034223 & 0.49050759 & 48 & 1.10694387 & 2.82498509 \\
\hline 18 & -0.56561932 & -0.07520349 & 49 & 1.90426518 & 0.18332737 \\
\hline 19 & -0.03134937 & 0.0763164 & 50 & -0.56946166 & 0.11426863 \\
\hline 29 & -0.1857603 & 0.65053957 & 51 & -0.70907001 & 0.19907141 \\
\hline 21 & 1.834319 & 1.11967484 & 52 & 0.85925159 & 0.55449098 \\
\hline 22 & 2.98579087 & -0.18611613 & 53 & -0.56946166 & 0.11426863 \\
\hline 23 & 2.54257255 & -0.12510955 & 54 & 0.85925159 & 0.55449098 \\
\hline 24 & 2.27969398 & 1.18351809 & 55 & -8.11559905 & 0.18960954 \\
\hline 25 & 2.53033899 & 0.79746193 & 56 & 2.05708516 & 0.18198642 \\
\hline 26 & 0.81109534 & 1.8214371 & 57 & -8.27783326 & 0.17195443 \\
\hline 27 & 0.65231039 & 1.41079016 & 58 & -8.55843778 & 0.17195443 \\
\hline 28 & 1.15226853 & 0.16166469 & 59 & 2.05708516 & 0.18198642 \\
\hline $\mathrm{B} 2$ & 1.40631888 & 0.20959798 & 60 & 2.05708516 & -0.72794568 \\
\hline 30 & 3.6114026 & -1.46768825 & 61 & -8.11559905 & -3.60258127 \\
\hline 31 & 3.6580072 & -0.13505624 & & & \\
\hline
\end{tabular}




\section{Conclusions}

The physicochemical groundwater quality of the Quaternary aquifer suggested that the studied water wells were heavily contaminated with nitrate, nitrite and ammonium in the strongly urbanized areas at Treichville, Koumassi, Marcory, Port-Bouët and Grand-Bassam. The presence of these nitrogen compounds could have significant health risks for local populations when well water is used as drinking water. In both seasons, $9.83 \%$ exhibited poor water quality and $3.27 \%$ indicated unsuitable water for drinking purposes. The groundwater samples irrespective of seasons fell in mixed $\mathrm{K}-\mathrm{Na}-\mathrm{HCO}_{3}$ and $\mathrm{K}-\mathrm{Na}-\mathrm{Cl}$ types. Relationships between physicochemical parameters show that intrusion of marine and lagoon waters and anthropogenic and natural/geogenic sources (rock-water interaction) were responsible for variation of physicochemical parameters in groundwater aquifer.

This study gave adequate background information on physiochemical parameters, water evaluation index, possible sources of pollution, controlling factors of groundwater quality and its spatial distribution in the study area. This paper is expected to help water resource planners taking adaptive measures for groundwater quality monitoring in the southern part of Abidjan District.

\section{Acknowledgements}

We would like to extend our sincere thanks to the local authorities (Treichville, Marcory, Port-Bouët, Koumassi, Grand-Bassam) and to the chiefs of villages (Abouabou, Maffiblé, Anani, Modeste, Moossou, Vitré 1 et Vitré 2) for allowing us to carry out different investigations in their jurisdiction.

\section{Conflicts of Interest}

The authors declare no conflicts of interest regarding the publication of this paper.

\section{References}

[1] Atwia, M.G., Mohamed, M., Abu-Heleika, M.M. and El-Horiny, M.M. (2013) Hydrogeochemical and Vertical Electrical Soundings for Groundwater Investigations, Burg El-Arab Area, Northwestern Coast of Egypt. Journal of African Earth Sciences, 80, 8-20. https://doi.org/10.1016/j.jafrearsci.2012.11.001

[2] Jellalia, D., Lachaal, F., Andoulsi, M., Zouaghi, T., Hamdi, M. and Bedir, M. (2013) Hydro-Geophysical and Geochemical Investigation of Shallow and Deep Neogene Aquifer Systems in Hajeb Layoun-Jilma-Ouled Asker Area, Central Tunisia. Journal of African Earth Sciences, 110, 227-244.

https://doi.org/10.1016/j.jafrearsci.2015.06.016

[3] Anomohanran, O. (2015) Hydrogeophysical Investigation of Aquifer Properties and Lithological Strata in Abraka, Nigeria. Journal of African Earth Sciences, 102, 247-253. https://doi.org/10.1016/j.jafrearsci.2014.10.006

[4] Abu Risha, U.A. and Al Temamy, A.M.M. (2016) Comparative Study of Factors Controlling the Groundwater Occurrence in Bir Kiseiba and Bir El Shab Areas, South Western Desert, Egypt Using Hydrogeological and Geophysical Technique. 
Journal of African Earth Sciences, 117, 183-195.

https://doi.org/10.1016/j.jafrearsci.2016.02.005

[5] Anaba Onana, A.B., Ndam Ngoupayou, J.R. and Mvondo Ondoa, J. (2017) Analysis of Crystalline Bedrock Aquifer Productivity: Case of Central Region in Cameroon. Groundwater for Sustainable Development, 5, 66-74.

https://doi.org/10.1016/j.gsd.2017.05.003

[6] Haj-Amor, Z., Hashemi, H. and Bouri, S. (2018) The Consequences of Saline Irrigation Treatments on Soil Physicochemical Characteristics. Euro-Mediterranean Journal for Environmental Integration, 3, 2-12. https://doi.org/10.1007/s41207-018-0064-y

[7] Hamad, A., Baali, F., Hadji, R., Zerrouki, H., Besser, H., Mokadem, N. and Hamed, Y. (2018) Hydrogeochemical Characterization of Water Mineralization in Tebessa-Kasserine Karst System (Tuniso-Algerian Transboundry Basin). Euro-Mediterranean Journal for Environmental Integration, 3, 7. https://doi.org/10.1007/s41207-017-0045-6

[8] Boujghad, A., Bouabdli, A. and Baghdad, B. (2019) Groundwater Quality Evaluation in the Vicinity of the Draa Sfar Mine in Marrakesh, Morocco. Euro-Mediterranean Journal for Environmental Integration, 4, 12. https://doi.org/10.1007/s41207-018-0096-3

[9] El Baghdadi, M., Zantar, I., Jouider, A., Nadem, S. and Medah, R. (2019) Evaluation of Hydrogeochemical Quality Parameters of Groundwater under Urban Activities. Case of Beni Mellal City (Morocco). Euro-Mediterranean Journal for Environmental Integration, 4, 5-19. https://doi.org/10.1007/s41207-018-0087-4

[10] Selvakumar, S., Chandrasekar, N. and Kumar, G. (2017) Hydrogeochemical Characteristics and Groundwater Contamination in the Rapid Urban Development Areas of Coimbatore, India. Water Resources and Industry, 17, 26-33. https://doi.org/10.1016/j.wri.2017.02.002

[11] Srivastava, K.S. and Ramanathan, L.A. (2008) Geochemical Assessment of Groundwater Quality in Vicinity of Bhalswa Landfill. Delhi; India by Using Graphical and Multivariable Statistical Methods. Environmental. Geology, 53, 1509-1528. https://doi.org/10.1007/s00254-007-0762-2

[12] Goné, D.L., Douagui, G.A., Bai, L., Kamagaté, B. and Ligban, R. (2014) Using Graphical and Multivariate Statistical Methods for Geochemical Assessment of Groundwater Quality in Oumé Department (Côte d'Ivoire). Journal of Environmental Protection, 5, 1255-1265. https://doi.org/10.4236/jep.2014.512119

[13] Toth, J. (1984) The Role of Regional Gravity Flow in the Chemical and Thermal Evolution of Groundwater. Proceedings of the First Canadian/American Conference on Hydrogeology, Alterta, Canada, 22-26 June 1984.

[14] Douagui, G.A., Kouamé, K.I., Koffi, K., Goula, B.T.A., Dibi, B., Goné, D.L., Coulibaly, K., Seka, M.A., Kouassi, K.A., Mangoua, O.M.J. and Savané, I. (2012) Assessment of the Bacteriological Quality and Nitrate Pollution Risk of Quaternary Groundwater in the Southern Part of Abidjan District (Côte d'Ivoire). Journal of Hydro-Environment Research, 6, 227-238.

https://doi.org/10.1016/j.jher.2012.05.001

[15] Kouamé, K.I., Douagui, G.A., Koffi, K., Dibi, B., Kouassi, K.L. and Savané, I. (2013) Modeling of Quaternary Groundwater Pollution Risk by GIS and Multicriteria Analysisin the Southern Part of Abidjan District (Côte d'Ivoire). Journal of Environmental Protection, 4, 1213-1223. https://doi.org/10.4236/jep.2013.411139

[16] Savané, I., Goula, B.T.A., Douagui, G.A. and Kouamé, K.I. (2006) Vulnerability As- 
sessment of Abidjan Quaternary Aquifer Using the DRASTIC Method. In: Xu, Y. and Usher, B., Eds., Groundwater Pollution in Africa, Taylor \& Francis/Balkema, Leiden, 115-124.

[17] Ahoussi, K.E., Soro, N., Soro, G., Lasm, T., Oga, M. and Zade, S.P. (2008) Groundwater Pollution in Africa's Biggest Towns: The Case of the Town of Abidjan (Co^te d'Ivoire). European Journal of Scientific Research, 20, 302-316.

[18] Douagui, G.A. (2012) Risques de pollution de la nappe du Quaternaire de la zone sud du District d'Abidjan: Cas du secteur Canal de Vridi-Grand-Bassam (Côte d'Ivoire). Thèse de Doctorat, Université Nangui Abrogoua, $150 \mathrm{p}$.

[19] Douagui, G.A., Kouamé, K.I., Koffi, K., Dibi, B., Konan, K.F. and Savané, I. (2009) Origines et modélisation de la minéralisation des eaux du Quaternaire d'Abidjan (Sud de la Côte d'Ivoire). International Journal of Biological and Chemical Sciences, 3, 856-869. http://ajol.info/index.php/ijbcs

[20] Lamrani, A.H., Oufdou, K. and Mezrioui, N. (2008) Environmental Pollution Impacts on the Bacteriological and Physicochemical Quality of Suburban and Rural Groundwater Supplies in Marrakesh Area (Morocco). Environmental Monitoring and Assessment, 145, 195-207. https://doi.org/10.1007/s10661-007-0029-0

[21] Tayfur, G., Kirer, T. and Baba, A. (2008) Groundwater Quality and Hydrogeochemical Properties of Torbalı Region, Izmir, Turkey. Environmental Monitoring and Assessment, 146, 157-169. https://doi.org/10.1007/s10661-007-0068-6

[22] WHO (2011) Guidelines or Drinking-Water Quality. 4th Edition, World Health Organization, Geneva.

[23] Vasanthavigar, M., Srinivasamoorthy, K., Vijayaragavan, K., Rajiv Ganthi, R., Chidambaram, S., Anandhan, P., Manivannan, R. and Vasudevan, S. (2010) Application of Water Quality Index for Groundwater Quality Assessment: Thirumanimuttar Sub-Basin, Tamilnadu, India. Environmental Monitoring and Assessment, 171, 595-609. https://doi.org/10.1007/s10661-009-1302-1

[24] Bhuiyan, H.A.M., Bodrud-Doza, M., Towfiqul Islam, A.R.M., Rakib, M.A., Rahman, M.S. and Ramanathan, A.L. (2016) Assessment of Groundwater Quality of Lakshimpur District of Bangladesh Using Water Quality Indices, Geostatistical Methods, and Multivariate Analysis. Environmental Earth Sciences, 75, 1-23.

[25] Landreau, A. and Monition, L. (1977) Nouvelle évaluation de la qualité de l'eau pour l'irrigation. Ministère de L'industrie, du Commerce et de l'artisanat, bureau de Recherches Géologiques Et Minières service Géologique National. 24 p. 